\title{
The Influence of Sense of School Community on Korean Students' Life Satisfaction and Comparison of Sense of Community for Students' Gender and High School Specialties
}

\author{
HwaChoon Park, Sangsoo Lee \\ Pusan National University, Korea
}

\begin{abstract}
The purpose of this study was to compare the sense of community of South Korean high school students as measured by a Korean version of the Sense of Community Index 2 (KSCI2) and examine the effect of two factors of the KSCI2, reinforcement of needs and influence, on students' life satisfaction as measured by the Satisfaction with Life Scale (SWLS). A total of 375 Korean high school students provided usable data from three vocational high schools specializing in agriculture, electronics and engineering, and business and marketing, and one Meister high school specializing in automotive. Descriptive statistics, independent $t$-test, one-way ANOVA, and path analysis with structural equation modeling (SEM), were performed to analyze data. Findings suggested that there were statistically significant differences in reinforcement of needs, influence, and life satisfaction, for the gender of students and school specialties. First, male students scored higher than female students on reinforcement of needs and influence. Next, male students were more satisfied with their lives than female students. For reinforcement of needs, students specializing in automotive scored higher than those specializing in business and marketing. For influence, students specializing in automotive scored higher than those specializing in all the other three specialties. Finally, both factors of reinforcement of needs and influence had positive effects on students' life satisfaction. Implications and suggestions for further studies are discussed.
\end{abstract}

Keywords: Korean Sense of Community Index 2, reinforcement of needs, influence, life satisfaction, school community

School is often considered an essential community that influences students' development as well as academic outcomes (Angelle, 2017; Dove, Zorotovich, \& Gregg, 2018; Osterman, 2000). A school community includes members and systems (Dove, Zorotovich, \& Gregg, 2018). School community members consist primarily of students and teachers (Osterman, 2000), as well as families and school leaders such as principals, school administrators, and school staff (Angelle, 2017; Dove, Zorotovich, \& Gregg, 2018). Social activities that occur between these community members provide students with opportunities to develop prosocial behaviors (Grover, Limber, \& Boberiene, 2015) including social and emotional skills, moral behaviors (Organisation for Economic Co-operation and Development [OECD], 2013), commitment to hard work, and high expectations of success (Osterman, 2000). Thus, cultivating students' 
sense of a school community is an important task for schools.

However, when looking into the current situation of schools in South Korea, public distrust and doubt over school administration and records escalated in contemporary Korean society. For example, manipulation of students' grades by teachers, leaks of exam questions, a lack of security, and teachers' unethical behaviors toward students including sexual abuse at many high schools are some examples that have affected school communities in South Korea (Kim, 2018). In 2012, the Programme for International Student Assessment (PISA) evaluated 15-year-old students' happiness at school for the first time, and students in South Korea reported the lowest score among the 64 participating countries (OECD, 2013). On average across the OECD countries, $80 \%$ of students reported that they agreed or strongly agreed with the statement "I feel happy at school" (OECD, 2013, p. 33), in contrast with about $60 \%$ of Korean students (OECD, 2013). Further, South Korean students' sense of belonging to their school has changed less than 5\% over the past ten years from 2003 to 2012 (OECD, 2013). South Korea reports the highest suicide rate of teenagers among the OECD countries (OECD, 2015) which may be an indicator of how unhappy or unsatisfied Korean students feel. Moreover, the suicide rate among teenagers in South Korea has not improved over the past decade (Lim, Ha, \& Song, 2014). Despite issues, South Korea lacks research on students who are key members of school communities. Along with families, schools and the education system can also cultivate students' overall well-being (OECD, 2013), and students' overall well-being is associated with student suicide. According to Voracek (2009), life satisfaction is an explicit factor that can prevent suicidal behaviors at the individual level. In addition, students' positive school experiences such as liking school and feeling connected to school affect students' mental and physical well-being (Currie et al., 2012). For example, students' sense of belonging, or how connected students feel to their school and peers (OECD, 2013), is also a factor of sense of a school community (McMillan \& Chavis, 1986; Osterman, 2000) and can be an obvious indicator of students' overall well-being such as social connectedness, happiness, and satisfaction at school (OECD, 2013).

However, research studies on how teen-aged students sense their schools as a community and how students' sense of a school community affects their life satisfaction are sparse in South Korea. Specifically, students' life satisfaction in vocational high schools has rarely been explored. Considering that students in vocational high schools tend to directly enter the workplace right after they graduate from school, their high schools can be the last community where they learn and develop a sense of a community before they transit from school to the workplace. Teenagers' experiences in school can affect their life satisfaction for the rest of their lives (Grover, Limber, \& Boberiene, 2015). Understanding how students sense their schools as a community and how this sense affects students' life satisfaction can help schools change systematic structures and develop programs that can promote students' life satisfaction and reduce the suicide rate among teenagers in South Korea.

\section{Literature Review}

Sense of Community. The sense of community refers to the feeling of the relationship that an individual holds for his or her community (McMillan \& Chavis, 1986; Sarason, 1974). It is a personal knowledge that he or she has about belonging to 
a collective of others (McMillan \& Chavis, 1986; Sarason, 1974) and a perception that one is similar to others. People acknowledge interdependence with others and have a willingness to give to and do for others what a person expects from them to maintain the interdependence (McMillan \& Chavis, 1986; Sarason, 1974).

A community can form as a result of place or relationships (Angelle, 2017). Communities emerge and form based on geographical territories such as blocks, neighborhoods, towns, cities, churches, colleges, clubs, rituals, celebrations, schools, hospitals, and markets, which are considered "territorial communities" (McMillan \& Chavis, 1986, p. 8). Due to more advanced communication technology and transportation technologies (Dunham, 1977; McMillan \& Chavis, 1986), communities can shape based on a process or a relationship (Dunham, 1977, 1986; McMillan \& Chavis, 1986) such as online social networks, news magazines, political parties, and YouTube channels, which are "relational communities" (McMillan \& Chavis, 1986, p. 8).

McMillan and Chavis (1986) insisted that four characteristics are usually found where a community emerges: "(a) membership, (b) influence, (c) integration and fulfillment of needs, and (d) shared an emotional connection" (p. 9). Membership refers to a feeling of belonging and emotional safety that allow members to participate in intimate social activities in the community (Angelle, 2017; McMillan \& Chavis, 1986; Osterman, 2000; Pooley, Pike, Drew, \& Breen, 2002). According to McMillan and Chavis (1986), membership includes five attributes: "boundaries, emotional safety, a sense of belonging and identification, personal investment, and a common symbol system" (p. 11), which are interwoven with each other and can be a sign of belonging to a community. Influence refers to a member's cohesiveness and conformity in the community. Influence is bidirectional: a member can influence the community and the community can impact a member (McMillan \& Chavis, 1986). Integration and fulfillment of needs refer to the reinforcement of members' needs, which is based on Maslow's theory of human motivation that basic human needs should be met before higher order needs can be met (Maslow, 1943). This concept includes the status of being a member, members' competence, motivation, and group success (McMillan \& Chavis, 1986). In other words, it means how well a member fits the community or how well a community fits a member. Shared values attract members to join the community, which enables their needs and goals to be better met and obtained (Angelle, 2017; McMillan \& Chavis, 1986; Osterman, 2000; Pooley et al., 2002). Finally, shared emotional connection refers to sharing history, time, experiences, and places among community members (McMillan \& Chavis, 1986). It works together with learning about the history of a community, frequent and clear interactions and tasks, positive relationships, frequent shared events, investment of time, energy, and intimacy (McMillan \& Chavis, 1986). Although not all communities have these four characteristics, every community has certain characteristics that attract people and enable members to perform social activities.

School Community. Many researchers agree that school is a community (Angelle, 2017; Grover, Limber, \& Boberiene, 2015; Osterman, 2000). Dewey (1966) viewed school as a social institution and emphasized that students can develop social skills through collaborative activities for experiential learning. As a social institution, schools have characteristics of a community (Angelle, 2017; Grover, Limber, \& Boberiene, 
2015; Osterman, 2000). For example, students feel that they belong to their school when they experience events together, spend time together, have their own symbols, are influenced, address their needs, are interdependent, and are emotionally connected to others at school (Grover, Limber, \& Boberiene, 2015). Students with higher perceptions of their school as a community, such as a feeling of being accepted by peers and teachers, tend to have a lower level of anxiety (Osterman, 2000).

According to Grover, Limber, and Boberiene (2015), for a school to become a good community, a school must be (a) a place that students perceive to be safe and fair, (b) a place that students are encouraged to actively participate in school activities, (c) a place that positive relationships with other members are promoted, and (d) a place where students want to stay. Thus, in this study, a school community is defined as a place where social, emotional, systematic interactions actively occur among school community members, i.e., teachers, students and families, school leaders, and school staff, in order to accomplish the shared goals of a school.

Life Satisfaction. Life satisfaction, also called global life satisfaction, (Suldo \& Huebner, 2004) can be defined as a person's cognitive and global evaluations of the quality of their lives as a whole based on their own standards (Pavot \& Diener, 2008; Suldo \& Huebner, 2004). Life satisfaction may function as a person's strength (Suldo \& Huebner, 2004). Chen, Wu, Lin, and Ye (2018) described life satisfaction as "the comparison between self-imposed standards and real conditions in one's overall life" (p. 1). As the discrepancy becomes smaller, a person is more satisfied with their life (Chen et al., 2018).

A person's life satisfaction is usually measured based on evidence of evaluations of factors such as "housing, health, education, work-life balance, environmental quality, social connections, civic engagement and governance, personal safety, income and wealth, jobs and earnings, and subjective well-being (OECD, 2017, p. 30)." A person's life satisfaction can also be evaluated by specific domain satisfaction such as marital satisfaction, job satisfaction, and satisfaction of housing since domain satisfaction is associated with life satisfaction (Pavot \& Diener, 2008). Life satisfaction is considered one of the three components of individuals' subjective well-being: "negative affect, positive affect and life satisfaction" (Pavot \& Diener, 2008, p. 138), which represent people's current feelings (OECD Better Life Index, 2018).

Top-down, Bottom-up, and Reciprocal Process on Life Satisfaction. Pavot and Diener (2008) examined life satisfaction judgments. They found that researchers on life satisfaction adopted either a top-down or a bottom-up model. Top-down models hypothesize that a person's temperament or personality is a strong and stable determinant of life satisfaction. Top-down models explain the variance of life satisfaction with personality variables rather than with life events or changes of specific domains. Thus, this perspective emphasizes the influence of a person's temperament on life satisfaction and minimizes the influence of continuous life experience on a person's subjective well-being (Pavot \& Diener, 2008).

Bottom-up models suggest that domain satisfactions affect a person's life satisfaction (Pavot \& Diener, 2008). Domain satisfaction refers to an evaluation of a specific domain of one' life such as marital satisfaction, school life satisfaction, and job satisfaction (Pavot \& Diener, 2008). That is, sums and combinations of domain 
satisfaction can account for the various levels of life satisfaction. Thus, events and changes in some life domains such as acquiring a long-term disability can explain longterm variations of a person's life satisfaction (Lucas, 2007; Pavot \& Diener, 2008). For example, past studies revealed that a person's marital satisfaction accounted for their life satisfaction (Lance, Lautenschlager, Sloan, \& Varca, 1989).

Finally, some past studies also examined the bidirectional process between topdown and bottom-up processes. For example, Chen et al. (2018) examined the reciprocal relationship between athletes' team satisfaction and life satisfaction. The findings of their study indicated a bidirectional association between team satisfaction and life satisfaction even though the estimates were more supported by the bottom-up process.

Researchers have not agreed on which model is better. However, many researchers agreed that domain satisfaction is a critical element for judging life satisfaction (Lance et al., 1989; Schimmack \& Oishi, 2005; Schneider \& Schimmack, 2010). Therefore, major life events and changes in life domains provide information on life satisfaction judgments. For this study, it was hypothesized that students' sense of a school community is one domain of students; life satisfaction would influence students' overall life satisfaction, and therefore, the bottom-up process was applied.

Sense of School Community and Life Satisfaction. According to Diener, Emmons, Larsen, and Griffin (1985), people tend to develop an optimistic outlook to carefully accumulate positive experiences which can strengthen life satisfaction. Research on school community offers insights into students' life satisfaction. Past studies revealed that students' sense of school community is associated with students' outcomes, behaviors, and overall well-being (OECD, 2013). For example, students with a higher sense of school community showed higher scores on standardized tests, better grades, and lower dropouts (Grover, Limber, \& Boberiene, 2015). Moreover, a higher sense of school community increases students' motivation, self-efficacy, active classroom participation, and sense of trust (Grover, Limber, \& Boberiene, 2015). A sense of school community is substantially related to life satisfaction as well (Grover, Limber, \& Boberiene, 2015). For example, a sense of school community affects students' mental, social, and emotional well-being (Grover, Limber, \& Boberiene, 2015). A sense of school community can also be predictors of students' prosocial behaviors such as empathy, concern for others, and helping others (Grover, Limber, \& Boberiene, 2015). For example, students who feel a strong sense of school community have less emotional distress, depression, anxiety, and suicidal ideation, leading to fewer suicide attempts (Grover, Limber, \& Boberiene, 2015; Osterman, 2000).

According to the result of a study conducted by OECD in 2012 that examined students' sense of belonging to their own schools, the percentage $(76.3 \%, S E=1.0)$ of Korean students who reported agree or strongly agree to the statement, I feel like I belong at school, was less than the OECD average (81.3\%, $S E=0.1)$ (OECD, 2013, p. $251)$. In addition, $60.4 \%(S E=1.0)$ of Korean students agreed or strongly agreed to the statement, I feel happy at school, which was also less than the OECD average $(79.8 \%$, $S E=0.1)(\mathrm{OECD}, 2013$, p. 32). To the statement, I am satisfied with my school, $65.0 \%$ $(S E=1.3)$ of Korean students agreed or strongly agreed, while the OECD average was $78.2 \%$ ( $S E=0.2)(\mathrm{OECD}, 2013$, p. 251). The overall mean of Korean students' sense of belonging to their schools was less than the OECD average by -0.32 point $(S E=0.02)$ 


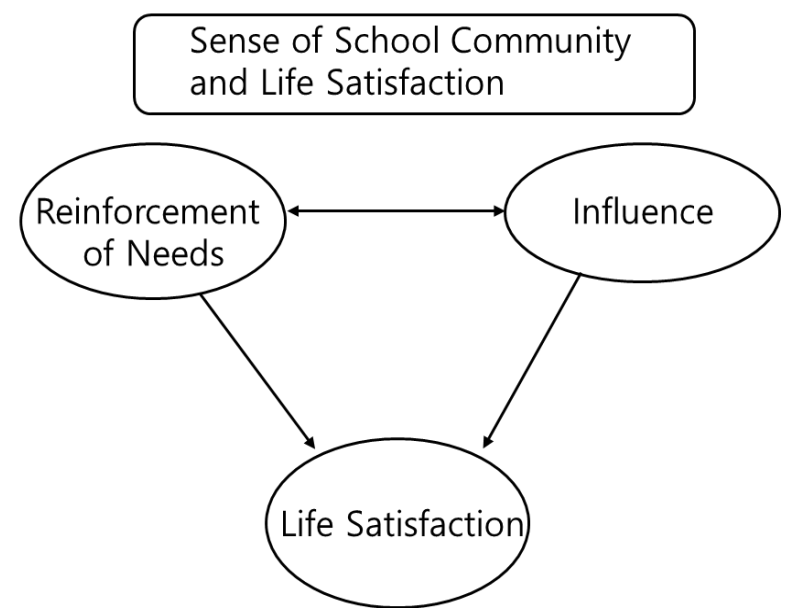

Figure 1. A conceptual path model between a sense of school community and life satisfaction. Reinforcement of needs and influence are the two factors of the Korean version of the sense of school community index 2 (Park, 2018).

(OECD, 2013, p. 54). Also, it was revealed that boys reported a higher mean index of a sense of belonging to a school than girls did by 0.08 point $(S E=0.04)$, and the gap was different from country to country (OECD, 2013, p. 54).

A conceptual hypothesis of path relationships between students' sense of school community and students' life satisfaction can be drawn based on literature on the school community and life satisfaction. Two factors that consist of a sense of school community were selected based on one of the precedent research studies for the current study, which examined the construct validity and reliability of the Korean version of the Sense of School Community Index 2 (KSCI2) (Park, 2018). When the KSCI2 was administered in Korean secondary school communities, only two factors were statistically meaningfully extracted, and the combinations of the items were slightly different from the SCI2 (Park, 2018). These two factors of the KSCI2 were "reinforcement of needs" and "influence" (Park, 2018) and were incorporated into the conceptual model for this study (Figure 1).

In order for schools to develop their own unique culture and fulfill their role as a community, it is important to clearly understand their students. Even though the concept of school community is perceived as important in South Korea, research on school community (more commonly called educational community) has been mainly limited to teachers or teachers' perceptions toward students, principals, and parents: teachers' competencies, interactions, and trust in secondary schools. Recently, Lee and Kim (2018) examined the relationship among empathic school community competency, sense of community, and subjective well-being with participants from general and special high school students in South Korea. One of the findings of their study revealed that students from general high schools scored higher on overall sense of a school community than those from special high schools in Korea.

However, research studies focusing on the specialties of vocational high schools in South Korea have not been conducted yet despite the fact that school specialties vary from school to school unlike general high schools. Also, research studies with participants of students in vocational or career and technical education (CTE) or Meister high schools are sparse. Considering that students' perceptions of the school community in CTE and Meister high schools have been minimally explored, it is 
Table 1. Numbers of High Schools and Students in South Korea

\begin{tabular}{llll}
\hline Year & School category & N of schools & N of students \\
\hline 2010 & General high school & 1,561 & $1,496,227(76.25 \%)$ \\
(until 2010) & Vocational high school & 693 & $466,129(23.75 \%)$ \\
& Total & 2,254 & $1,962,356$ \\
2018 & & & \\
(since 2011) & General high school & 1,556 & $1,096,331(71.26 \%)$ \\
& Special-purposed high school & 157 & $66,693(4.33 \%)$ \\
& Vocational high school (CTE) & 490 & $252,260(16.40 \%)$ \\
& Autonomous high school & 155 & $123,292(8.01 \%)$ \\
& $\quad$ Total & 2,358 & $1,538,576$ \\
\hline
\end{tabular}

Note. Special schools for children with disabilities and for adults were not included. Resources were based on the statistics that Minister of Education Korea provided (Minister of Education Korea, 2018b).

Table 2. Sense of Community Index 2 and Korean Sense of School Community Index 2

\begin{tabular}{lll}
\hline & Sense of Community Index 2 & Korean Sense of School Community Index 2 \\
\hline \multirow{2}{*}{ Factors } & $\begin{array}{l}\text { Reinforcement of needs (6 items) } \\
\text { Membership (6 items) } \\
\text { Influence (6 items) } \\
\text { Shared emotional connection (6 items) }\end{array}$ & $\begin{array}{l}\text { Reinforcement of needs (8 items) } \\
\text { Influence (5 items) }\end{array}$ \\
Reliability & $\begin{array}{l}\text { Cronbach's } \alpha=.94 \text { (total) } \\
\text { Cronbach's } \alpha \text { ranges from .79 to .86 }\end{array}$ & $\alpha=.92, \alpha=.83$, respectively \\
Sample item & $\begin{array}{l}\text { This community has been successful in getting the } \\
\text { needs of its members met. }\end{array}$ & $\begin{array}{l}\text { My school community has been successful in } \\
\text { getting the needs of students met. }\end{array}$ \\
\hline
\end{tabular}

Note. Information of the table was based on Chavis, Lee, \& Acosta (2008) and Park (2018). The full items of the SCI2 are available for free upon request through the website called, Sense of Community: https://www.senseofcommunity.com/soc-index/. The full version of the KSCI2 is available in Park's validation study (Park, 2018).

meaningful to investigate how students in CTE and Meister high schools feel their schools as a community and how the factors of the sense of school community affect students' life satisfaction. This study can be a beginning point for researchers on CTE school communities in South Korea.

Thus, this study is about the relationship between schools including educational systems and students' life satisfaction in the school community context to help improve students' overall well-being. Findings of the study can contribute to the existing research on the school community in South Korea and provide a basis for schools to change school structures and develop programs and activities for cultivating students' sense of school community and improving students' life satisfaction.

\section{Purpose of the Study}

The purpose of this study was to describe, compare, and investigate how students in career and technical education high schools in South Korea would perceive their schools as a community. Specifically, it sought to answer three research questions:

- How is students' sense of school community different according to student gender?

- How is students' sense of school community different according to different vocational high school specialties? 
- How does students' sense of school community affect students' life satisfaction among vocational and Meister high school students?

\section{Methods}

Context of High Schools in South Korea. In the past, South Korean high schools were categorized into two tracks: general high schools for colleges and vocational high schools for entering the workplace right after high school (Table 1). Since 2011, high schools have been categorized into four types: (a) general high schools for academic purposes and college admissions, (b) special-purposed high schools for science, foreign languages, arts (e.g., music, dance, literacy, play), sports, international professions, and Meister (special CTE), (c) vocational high schools (CTE), and (d) autonomous high schools (Minister of Education Korea, 2018a). The Korean government launched Meister high schools, which were specifically designed for the purpose of operating a customized curriculum linked directly to industry demand for the development of professional vocational education, in 2010. Many former CTE high schools reformed and became Meister high schools. In 2018, there are a total of 49 Meister high schools in South Korea (HIFIVE, 2018).

Sample and Participant Selection. The target participants of this study included high school students in vocational high schools and Meister high schools, which are considered CTE high schools in South Korea. The study was approved by the IRB at the institution that the authors are affiliated. A non-probability convenience sampling method was used in this study, which means that every potential participant does not have an equal chance to be chosen as a participant (Johnson \& Christensen, 2014). Through a non-probability convenience sampling, participants can be easily recruited from people who are available or have a willingness to participate in the research survey (Johnson \& Christensen, 2014).

For this study, social and professional networks were used by the researchers, recruiting teachers and principals whom the authors are acquainted. Principals of 10 vocational and Meister high schools in total were first contacted in Busan and Ulsan, two of the six metropolitan cities in South Korea, and Gyungsang and Jeolla provinces, two of the six main provinces in South Korea. Next, the purpose of the study was explained to the principals of selected schools. Three principals from vocational high schools and one principal from a Meister high school permitted the researchers to administer the surveys at their schools. The specialties of the three CTE high schools were Agriculture, Electronics and Engineering, and Business and Marketing, respectively. The specialty of the Meister high school was Automotive. A total of 440 copies of survey questionnaires with candies as a reward were sent to the four schools by mail, and 410 copies were returned. After coding and screening the data, a total of 375 responses were used for the analysis as a sample. Male students were $241(64.3 \%)$, $149(39.7 \%)$ were in $10^{\text {th }}$ grade, $158(42.1 \%)$ were in $11^{\text {th }}$ grade, and $68(18.1 \%)$ were in $12^{\text {th }}$ grade students. In terms of CTE specialty, 100 (26.7\%) students were from an Agriculture specialized high school, $110(29.3 \%)$ were from an Electronics and Engineering specialized high school, 101 (26.9\%) were from a Business and Marketing specialized high school, and 64 (17.1\%) were from an Automotive Meister high school. 


\section{Measures}

Korean version of the Sense of Community Index 2 (KSCI2). The Korean Sense of Community Index 2 (KSCI2) was used to measure how Korean CTE and Meister high school students sensed their schools as a community (Table 2). The KSCI2 is a self-reported Korean version of the Sense of Community Index2 (SCI-2; Chavis, Lee, $\&$ Acosta, 2008). While the SCI-2 consists of 24 statements and are categorized into four dimensions: membership, influence, meeting needs, and a shared emotional connection (Chavis, Lee, \& Acosta, 2008), the KSCI2 has 13 statements and are divided into two factors. The two factors of the Korean Sense of Community Index 2 were reinforcement of needs (e.g., "I get important needs of mine met because I am part of this school community) and influence (e.g., "This school community can influence other communities) with a four-point Likert-like scale $(1=$ not at all, $4=$ completely) (Park, 2018, pp. 10-11). Model indices of the two-factor model of the KSCI2 indicated a good fit with $\chi^{2}(78, n=290)=2592.46, p<.001, \mathrm{SRMR}=.04, \mathrm{TLI}=.92, \mathrm{CFI}=.94($ Park, 2018, p. 57). The coefficient alphas of the subscales were .92 and .83, respectively (Park, 2018, p. 59). Participants reported their self-assessments using a paper-based survey questionnaire.

Korean version of Satisfaction with Life Scale (SWLS). To measure Korean students' life satisfaction, the Korean version of the SWLS was used, which is freely available online (Diener, n.d.). The Satisfaction with Life Scale (SWLS) is designed to measure global cognitive judgments of satisfaction with one's life and consists of short five statements (Diener et al., 1985). The Korean version of SWLS has the same five short items (e.g., "I am satisfied with my life") and used a 5-point Likert scale (1= Strongly disagree, $5=$ Strongly agree). The KSWLS produced an adequate internal consistency with $\alpha=.92$.

\section{Data Analysis}

To examine the sense of school community of Korean vocational and Meister high school students, descriptive statistics were first produced including means and standard deviations $(S D$ s). Skewness and kurtosis of each item were also examined to check the modality of the distribution and detect outliers of the sample (DeCarlo, 1997). To compare means of the sense of school community for male and female students, the independent $t$-test was employed. To compare means of the sense of school community and life satisfaction for CTE specialty of the four high schools, an independent oneway ANOVA was performed with some post hoc tests, using SPSS Statistics 23.

To discover whether the effect was substantive, effect size indicators were calculated for each test. An effect size indicates the strength of a relationship between the independent and dependent variables and how big an effect is present (John \& Christensen, 2014). With effect size statistics, researchers can interpret the results of a study from a practical point of view (Gall, Gall, \& Borg, 2007). For this study, Pearson $r$ correlations were calculated, using the values of $r^{2}$ (Field, 2009). According to Cohen (1992), the effect size is low if the value of $r$ is around 0.1, medium if $r$ varies around 0.3 , and large if $r$ is more than 0.5 . In other words, the higher the effect size, the greater the difference exists between the groups compared. To examine the influence of sense 
Table 3. Test of Homogeneity of Variances

\begin{tabular}{lllll}
\hline & Levene statistic & $d f 1$ & $d f 2$ & Sig. \\
\hline Reinforcement of needs & 1.406 & 2 & 372 & .247 \\
Influence & 2.259 & 2 & 372 & .106 \\
Life satisfaction & .889 & 2 & 372 & .412 \\
\hline
\end{tabular}

Table 4. Results of Comparisons of Variances $(n=375)$

\begin{tabular}{lllllll}
\hline Variable & & $S S$ & $d f$ & $M S$ & $F$ & Sig. \\
\hline \multirow{4}{*}{ RN } & Between & 10.477 & 3 & 3.492 & 3.423 & .017 \\
& Within & 378.536 & 371 & 1.020 & & \\
& Total & 389.013 & 374 & & & \\
& & & & & & \\
IN & Between & 8.909 & 3 & 2.970 & 7.274 & .000 \\
& Within & 151.455 & 371 & .408 & & \\
& Total & 160.364 & 374 & & & \\
& Between & 4.351 & 3 & 1.450 & 2.060 & .105 \\
LS & Within & 261.127 & 371 & .704 & & \\
& Total & 265.478 & 374 & & & \\
\hline
\end{tabular}

Note. $\mathrm{RN}=$ reinforcement of needs, $\mathrm{IN}=$ influence, and $\mathrm{LS}=$ life satisfaction.

of school community on students' life satisfaction, a path analysis was performed, employing structural equation modeling (SEM) with Mplus7.

\section{Results}

Descriptive Statistics. Means, standard deviations, skewness, and kurtosis were calculated and examined. All the values of skewness were not greater than 2.0, and the values of kurtosis of all the items were less than 0.7 , which indicated that the normal distribution of the sample was assumed (DeCarlo, 1997).

Independent $\boldsymbol{t}$-test. Findings suggested that on average, male students $(n=241)$ sensed their schools as communities in reinforcement of needs $(M=4.525, S E=0.063)$ greater than female students $(M=4.100, S E=0.090)$, and it was statistically significant, $t(371)=3.903, p<.001, r=.20$, which indicated a medium-sized effect. For the factor of influence, male students $(M=2.821, S E=0.041)$ scored higher than female students $(M=2.530, S E=0.057)$, and it was statistically significant, $t(371)=4.056, p<.001, r$ $=.21$, which represented a medium-sized effect. In terms of life satisfaction, on average male students $(M=3.491, S E=0.051)$ were more satisfied with their lives than female students $(M=3.178, S E=$

$0.077)$ and the difference was also statistically significant, $t(371)=3.613, p<.001, r$ $=.18$, which showed a small-sized effect.

One-way ANOVA. Means of the sense of school community and life satisfaction 
Table 5. Multiple Comparisons Between CTE Specialty Using Tukey HSD ( $\mathrm{n}=375)$

\begin{tabular}{|c|c|c|c|c|c|c|}
\hline DV & Major (I) & Major (J) & MD (I-J) & $S E$ & Sig. & $95 \% \mathrm{CI}[L L, U L]$ \\
\hline \multirow{12}{*}{$\mathrm{RN}$} & $\mathrm{Ag}$ & El \& En & -.153 & .140 & .690 & {$[-.514, .207]$} \\
\hline & & $B \& M$ & .106 & .143 & .880 & {$[-.262, .474]$} \\
\hline & & Auto & -.380 & .162 & .089 & {$[-.797, .037]$} \\
\hline & El \& En & $\mathrm{Ag}$ & .153 & .140 & .690 & {$[-.207, .514]$} \\
\hline & & $B \& M$ & .259 & .139 & .246 & {$[-.100, .619]$} \\
\hline & & Auto & -.226 & .159 & .484 & {$[-.636, .183]$} \\
\hline & $B \& M$ & $\mathrm{Ag}$ & -.106 & .143 & .880 & {$[-.474, .262]$} \\
\hline & & El \& En & -.259 & .139 & .246 & {$[-.619, .100]$} \\
\hline & & Auto & $-.486^{*}$ & .161 & .015 & {$[-.902,-.069]$} \\
\hline & Auto & $\mathrm{Ag}$ & .380 & .162 & .089 & {$[-.037, .797]$} \\
\hline & & El \& En & .226 & .159 & .484 & {$[-.183, .636]$} \\
\hline & & B \& M & $.486^{*}$ & .161 & .015 & {$[.069, .902]$} \\
\hline \multirow{12}{*}{ IN } & $\mathrm{Ag}$ & El \& En & -.048 & .088 & .948 & {$[-.276, .180]$} \\
\hline & & $\mathrm{B} \& \mathrm{M}$ & .004 & .090 & 1.000 & {$[-.228, .237]$} \\
\hline & & Auto & $-.421^{*}$ & .102 & .000 & {$[-.685,-.157]$} \\
\hline & El \& En & $\mathrm{Ag}$ & .048 & .088 & .948 & {$[-.180, .276]$} \\
\hline & & $B \& M$ & .052 & .088 & .934 & {$[-.175, .280]$} \\
\hline & & Auto & $-.373^{*}$ & .100 & .001 & {$[-.632,-.114]$} \\
\hline & $B \& M$ & $\mathrm{Ag}$ & -.004 & .090 & 1.000 & {$[-.237, .228]$} \\
\hline & & El \& En & -.052 & .088 & .934 & {$[-.280, .175]$} \\
\hline & & Auto & $-.425^{*}$ & .102 & .000 & {$[-.689,-.162]$} \\
\hline & Auto & $\mathrm{Ag}$ & $.421^{*}$ & .102 & .000 & {$[.157, .685]$} \\
\hline & & El \& En & $.373^{*}$ & .100 & .001 & {$[.114, .632]$} \\
\hline & & $B \& M$ & $.425^{*}$ & .102 & .000 & {$[.162, .689]$} \\
\hline
\end{tabular}

Note. $\mathrm{DV}=$ dependent variable; $\mathrm{RN}=$ reinforcement of needs, $\mathrm{IN}=$ influence; $\mathrm{MD}=$ mean difference, $\mathrm{CI}=$ confidence interval for a difference, $L L=$ lower limit, $U L=$ upper limit; $\mathrm{Ag}=$ Agriculture, $\mathrm{B} \& \mathrm{M}=\mathrm{Business}$ and Marketing, Auto $=$ Automotive, $\mathrm{El} \& \mathrm{En}=$ Electronics and Engineering. ${ }^{*} p<.05$. and are in boldface.

for four different specialties were compared, using independent one-way ANOVA. First, Levene's test was performed to see whether the variances of the four groups were significantly different and the result suggested that the variances were very similar for the three variables of reinforcement of needs, influence, and subjective well-being (Table 3).

Means and standard deviations (SDs) were produced for each specialty of the four different high schools. For reinforcement of needs, the Meister high school which specialized in automotive scored the highest $(M=4.672, S D=0.822)$, the vocational high school specializing in electronics and engineering $(M=4.446, S D=1.068)$ scored second highest, the vocational high school specializing in agriculture the third highest $(M=4.292, S D=0.996)$, and the vocational high school in business and marketing was the lowest $(M=4.186, S D=1.066)$. For the factor of influence, results showed the same trend as reinforcement of needs: the Meister high school scored the highest $(M=3.053$, $S D=0.532)$, the vocational high school in electronics and engineering the second $(M$ $=2.680, S D=0.683)$, the vocational high school in agriculture the third highest $(M=$ 
Table 6. Correlation and Reliability $(\mathrm{n}=375)$

\begin{tabular}{llll}
\hline Variable & $\mathrm{RN}$ & $\mathrm{IN}$ & $\mathrm{LS}$ \\
$\mathrm{RN}$ & $(.922)$ & & \\
$\mathrm{IN}$ & $.687^{* *}$ & $(.847)$ & \\
$\mathrm{LS}$ & $.484^{* *}$ & $.486^{* *}$ & $(.898)$ \\
$M$ & 2.733 & 2.717 & 3.379 \\
$S D$ & 0.790 & 0.830 & 0.995 \\
\hline
\end{tabular}

Note. Values in the parentheses represent Cronbach's $\alpha . \mathrm{RN}=$ reinforcement of needs, $\mathrm{IN}=$ influence, and LS $=$ life satisfaction. $* *$ indicates $p<.001$.

2.632, $S D=0.652)$, the vocational high school in business and marketing scored the lowest $(M=2.628, S D=0.637)$. For students' life satisfaction, students in the Meister high school were most satisfied with their life $(M=3.609, S D=0.718)$, those in electronics and engineering the second $(M=3.362, S D=0.850)$, those in business and marketing did the third $(M=3.339, S D=0.921)$, and students in agriculture were least satisfied with their life $(M=3.292, S D=0.812)$.

There was a significant difference in means of the two factors of the KSCI2: reinforcement of needs and influence: $F(3,371)=3.423, p<.05, r=.16$ and $F(3,371)$ $=7.274, p<.05, r=.24$, respectively. However, there was not a significant difference in means of students' life satisfaction between the four specialties (Table 4).

Since there were four groups of high school specialties, some post hoc tests to compare means of all groups of participants were carried out. The results of Tukey HSD are presented (Table 5). For the factor of reinforcement of needs of the KSCI2, students specializing in automotive scored higher than those in business and marketing. The value of the difference was .486 and was statistically significant, $p<.05$. For the other groups, the differences in means of reinforcement of needs were not significant. The difference in means of the second factor of influence was statistically significant between students specializing in automotive and those in all the other specialties: agriculture, business and marketing, and electronics and engineering. The mean differences among other groups were not significant.

Path Analysis. To examine the effect of sense of school community on students' life satisfaction, a path analysis was conducted, using SEM. First, the correlation between variables was calculated; each variable was positively correlated with values from .484 to .687 . The internal consistency of each variable was produced, using Cronbach's $\alpha$, with the values of $\alpha$ ranging from .847 to .922 (Table 6).

The result of a path analysis suggested that the factor of reinforcement needs had a positive effect on students' life satisfaction $(\beta=.368, p<.001)$, and the factor of influence had a positive effect on students' life satisfaction $(\beta=.515, p<.001)$. The diagram of the model is produced, using Mplus7 (Figure 2).

Finally, to examine the model fit, several model indices of the confirmatory factor analysis were produced, using Mplus7. Model indices were $\chi^{2}(132, n=568)=521.813$, $p<.001, \mathrm{SRMR}=.04, \mathrm{TLI}=.92, \mathrm{CFI}=.94, \mathrm{RMSEA}=.07$ with $90 \%$ CI $[.065, .078]$ 


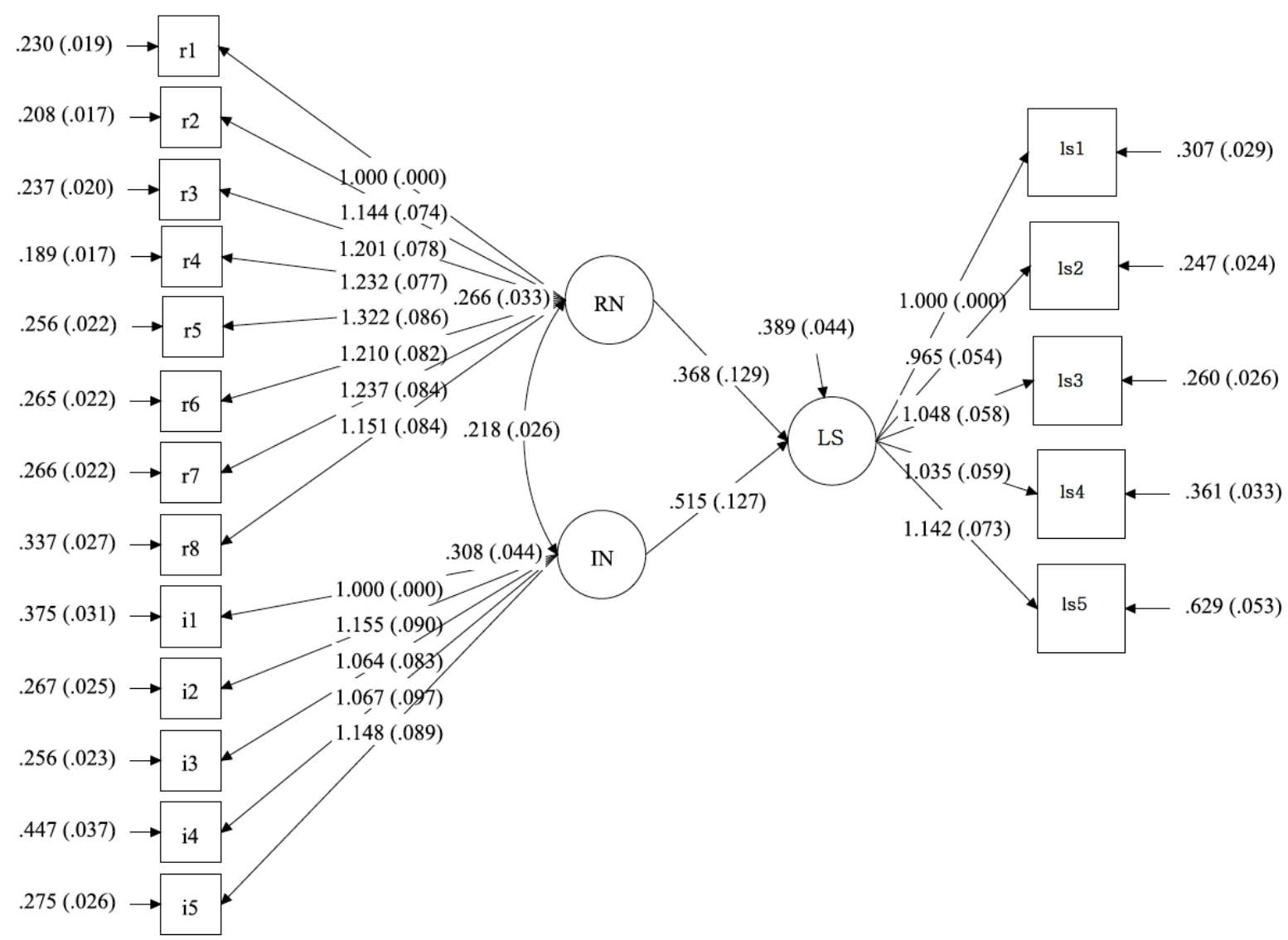

Figure 2. Empirical results from the structural equation modeling. Three latent variables are estimated: $\mathrm{RN}=$ reinforcement of needs, $\mathrm{IN}$ = influence, and LS = life satisfaction. The metric of the factors was set by fixing the first factor loading in each to 1 .

and $p<.001$ and indicated a very good fit to the sample data.

\section{Discussion and Conclusions}

In response to the first research question, "How is students' sense of school community different according to student gender?" male students perceived their schools as a community greater than female students did, reporting higher scores for reinforcement of needs and influence on the KSCI2. This result was consistent with the OECD (2013) finding that boys scored higher on a sense of belonging and feeling happy at school than girls did.

In response to the second research question, "How is students' sense of school community different according to different vocational high school specialties?" students in the Meister high school specializing in automotive scored greater on reinforcement of needs than those in the vocational high school specializing in business and marketing. Also, students in the Meister high school specialized in automotive felt the greater influence of their school community than those in the other three vocational high school specialties: agriculture, business and marketing, and electronics and engineering. These results imply that the Meister high school specializing in automotive 
may have reinforced students' needs such as a high rate of scholarship provided to students and a high rate of employment after graduation. However, the findings also imply further studies should be conducted to find out why students in the Meister high school felt their school as a community greater than those who attended the other vocational high schools. In addition, students who attend other Meister high schools should be examined to see whether they show similar indices in sense of school community or not.

In response to the third question, "How does students' sense of school community affect students' life satisfaction among vocational and Meister high school students?" students' life satisfaction was affected by the two factors of the sense of a school community: reinforcement of needs and influence. This result is consistent with the argument that a sense of school community is associated with students' mental and overall life satisfaction by Grover, Limber, and Boberiene (2015).

Past research has only minimally explored students' perspectives in terms of students' life satisfaction and their sense of school community, specifically utilizing students in vocational and Meister high schools. This study is unique because past research studies did not explain how male and female students differently sensed their schools as a community and how students' perceptions of the school community were different for different vocational specialties. This study also explored students' life satisfaction at the level of a school-life domain: students' sense of school community which further supports the importance of improving students' overall life satisfaction by cultivating a sense of school community.

As Currie et al. (2012) argued that policymakers and school practitioners need to consider school's influence on young people's lives, those in vocational high schools in South Korea need to consider that students' connections with school commonly decrease as they get older and reflect schools' influence on students' life satisfaction. In particular, to improve students' sense of school community, vocational high schools need to identify students' needs and reflect their needs in practices for changing school systems and structure and for developing programs and events. One way to cultivate students' sense of school community is to reinforce students' needs (Angelle, 2017; Grover, Limber, \& Boberiene, 2015). Schools need to identify what students know, what students want to learn, and what students need to learn. Specifically, principals and teachers in vocational high schools in South Korea should take more initiative to make their schools be better communities that can respect, care for, and support teenagers (Angelle, 2017). School leaders, teachers, and school staff in vocational high schools need to consider the distinct context for decision making and behaviors (Angelle, 2017).

Some practices for improving students' sense of community may include changing structures of school and classroom systems as Grover, Limber, and Boberiene (2015) suggested examples such as changing the classroom layout physically, keeping students with the same teacher for years to maintain continuous relationship and learning, and taking care of older students with teams of students.

Further, efforts should be complemented with nonstructural strategies such as promoting safety in school, increasing students and families' participation in policy development, delivering school rules and expectations clearly, promoting positive behaviors with appropriate reinforcement, and offering consistent and consequences when rules are violated. Positive relationships should also be encouraged between 
teachers, school leaders, school staff, students, and families. Respecting and greeting students with sincere interest, identifying academic and non-academic challenges that students face, providing appropriate counseling services and support, and seeking external collaboration to meet students' needs when schools cannot provide such services with internal resources can be some practical examples to cultivate the sense of community of students at the school level (Grover, Limber, \& Boberiene, 2015).

Practicing programs to improve students' sense of school community is also important. At the classroom and the individual levels, efforts by teachers should be made to complement prosocial behaviors such as social-emotional learning, soft skills, and citizenship (Grover, Limber, \& Boberiene, 2015). At the school level, principals need to seek collaboration and cooperation with families, community leaders, and community businesses for developing a sense of school community for students in CTE high schools. Finally, cultivating a sense of school community in students can be accomplished through efforts made by systematic connections, supports, and collaboration as well as by the independent role of each agent.

\section{Limitations and Recommendations for Future Research}

Despite the unique contribution to the research and literature on school community, this study has multiple limitations. First, this study could not identify the reasons why female students' sense of school community was lower than that of male students. Also, the two factors of the Korean version of the sense of school community index 2 may not represent all the aspects of students' sense of their school communities. In addition, this study did not investigate why the students in the Meister high school scored higher on a sense of their school community than those from the other three vocational high schools. Another limitation of this study was that the participants for this study were from two metro cities and two provinces in South Korea, which means that the findings of this study are hard to be generalized to all the students in vocational and Meister high schools in South Korea.

For future research, one possible suggestion is to conduct a study exploring why female students felt less of a sense of school community than their male counterparts. These findings can be of value and offer further data. Also, more Meister school systems and students can be explored to see which variables affect students' sense of school community compared to vocational high schools. In addition, a study similar to this should be conducted, utilizing different participants from more Meister and vocational high schools in different areas in South Korea. As noted as a limitation of this study, more participants are needed to represent vocational and Meister high school students. Also, studies utilizing students from different specialties in both vocational and Meister high schools would provide more meaningful insight into the relationship between students' sense of school community and life satisfaction.

Note: This research was supported by a grant from the National Research Foundation of Korea funded by the Korean Government (2017S1A3A2067778)

\section{References}

Angelle, P. S. (2017). Beliefs and behaviors of two high school principals in developing a 
sense of school community for students. NASSP Bulletin, 101(1), 5-22. https://doi.org $/ 10.1177 / 0192636517694957$

Chavis, D. M., Lee, K. S., \& Acosta, J. D. (2008). The sense of community (SCI) revised: The reliability and validity of the SCI-2. Paper presented at the 2 nd International Community Psychology Conference, Lisboa, Portugal.

Chen, L. H., Wu, C., Lin, S., \& Ye, Y. (2018). Top-down or bottom-up? The reciprocal longitudinal relationship between athletes' team satisfaction and life satisfaction. Sport, Exercise, and Performance Psychology, 7(1), 1-12. http://doi.org/10.1037 /spy0000086

Currie, C., Zanotti, C., Morgan, A., Currie, D., Looze, M. de, Roberts, C., Samdal, O., Smith, O. R. F., \& Barnekow, V. (Eds.). (2012). Social determinants of health and well-being among young people. Health Behaviour in School-aged Children (HBSC) study: International report from the 2009/2010 survey (Health Policy for Children and Adolescents, No. 6). Copenhagen, WHO Regional Office for Europe. Retrieved from http://www.hbsc.unito.it/it/images/pdf/hbsc/prelims-part1.pdf

Cohen, J. (1992). A power primer. Psychological Bulletin, 112(1), 155.

DeCarlo, L. T. (1997). On the meaning and use of kurtosis. Psychological Methods, 2(3), 292307. https://doi.org/10.1037/1082-989X.2.3.292

Dewey, J. (1966). Democracy and education: An introduction to the philosophy of education. New York, NY: The Free Press.

Diener, E. (n.d.). Satisfaction with Life Scale (SWLS). Retrieved from https://eddiener.com /scales/7

Diener, E., Emmons, R. A., Larsen, R. J., \& Griffin, S. (1985). The satisfaction with life scale. Journal of Personality Assessment, 49, 71-75.

Dove, M. K., Zorotovich, J., \& Gregg, K. (2018). School community connectedness and family participation at school. World Journal of Education, 8(1), 49-57. https://doi.org /10.5430/wje.v8n1p49

Dunham, H. W. (1977). Community as process: Maintaining the delicate balance. American Journal of Community Psychology, 5(3), 257-268.

Dunham, H. W. (1986). Commentary the community today: Place or process. Journal of Community Psychology, 14(4), 399-404.

Field, A. P. (2009). Discovering statistics using SPSS (3rd ed.). Los Angeles, CA: Sage

Gall, M., Gall, J., \& Borg, W. (2007). Educational research: An introduction (8th ed.). Boston, MA: Allyn \& Bacon.

Grover, H. M., Limber, S. P., \& Boberiene, L. V. (2015). Does it matter if students experience school as a place of community? American Journal of Orthopsychiatry, 85(6), S79-S85. https://doi.org/10.1037/ort0000131

HIFIVE. (2018). Meister school trends and status. [Web log post]. Retrieved from http://www.hifive.go.kr/school/meisterAppointField.do?rootMenuId=02\&menuId $=020203$

Johnson, B., \& Christensen, L. B. (2014). Educational research: quantitative, qualitative, and mixed approaches (5th ed.). Los Angeles, CA: Sage.

Kim, J. (2018, October 16). Distrust escalates over school records. The Korea Times: Hankook Ilbo. Retrieved from https://www.koreatimes.co.kr/www/nation/2018/10 /181_257094.html

Lance, C. E., Lautenschlager, G. J., Sloan, C. E., \& Varca, P. E. (1989). A comparison between bottom-up, top-down, and bidirectional models of relationships between global and life facet satisfaction. Journal of Personality, 57, 601-624. https://doi.org/10.1111 /j.1467-6494.1989.tb00565.x

Lee, S. S., \& Kim, E. J. (2018). $\square \square \square \square \square \square \square \square: \square \square \square \square \square \square \square \square \square \square \square \square \square \square \square$ [A study on the relationship among empathetic school community competency, sense of community, and 
subjective wellbeing: Focused on general and special high school students].

$\square \square \square \square \square \square$ [Educational Methodology Studies], 30(3), 307-328.

Lim, D., Ha, M., \& Song, I. (2014). Trends in the leading causes of death in Korea, 19832012. Journal of Korean Medical Science, 29(12), 1597-1603.

Lucas, R. E. (2007). Long-term disability is associated with lasting changes in subjective well-being: Evidence from two nationally representative longitudinal studies. Journal of Personality and Social Psychology, 92, 717-730.

Maslow, A. H. (1943). A theory of human motivation. Psychological Review, 50, 370-396.

McMillan, D. W., \& Chavis, D. M. (1986). Sense of community: A definition and theory. Journal of Community Psychology, 14(1), 6-23.

Minister of Education Korea. (2018a). Secondary education [Web log post]. Retrieved from http://english.moe.go.kr/sub/info.do?m=020103\&s=english

Minister of Education Korea. (2018b). Statistics: Overview [Web log post]. Retrieved from $\mathrm{http} / /$ english.moe.go.kr/sub/info.do?m=050101\&page $=050101 \&$ num $=1 \& \mathrm{~s}=$ english

Organisation for Economic Co-operation and Development. (2013). PISA 2012 Results: Ready to learn: Students' engagement, drive and self-beliefs (Volume III). PISA, OECD Publishing. https://doi.org/10.1787/9789264201170-en

OECD Better Life Index. (2018). Life satisfaction [Web log post]. Retrieved from http://www .oecdbetterlifeindex.org/topics/life-satisfaction/

Organisation for Economic Co-operation and Development. (2015). Health at a glance 2015: OECD indicators. OECD Publishing, Paris. https://doi.org/10.1787/health_glance-2015 -en

Organisation for Economic Co-operation and Development. (2017). How's life? 2017: Measuring well-being, OECD Publishing, Paris. https://doi.org/10.1787/how_life-2017 -en

Osterman, K. F. (2000). Students' need for belonging in the school community. Review of educational research, 70(3), 323-367.

Park, H. (2018). Korean Sense of Community Index 2 and students' sense of community in Korean secondary schools. Korean Social Science Journal, 5, 47-63. Retrieved from http://www.kossrec.org/?page_id=482\&ID=1505\&type=view

Pavot, W., \& Diener, E. (2008). The satisfaction with life scale and the emerging construct of life satisfaction. Journal of Positive Psychology, 3, 137-152. https://doi.org/10.1080 $/ 17439760701756946$

Pooley, J. A., Pike, L. T., Drew, N. M, \& Breen, L. (2002). Inferring Australian children's sense of community: A critical exploration. Community, Work and Family, 5(1), 5-22, https://doi.org/10.1080/13668800020006802a

Schimmack, U., \& Oishi, S. (2005). The influence of chronically and temporarily accessible information on life satisfaction judgments. Journal of Personality and Social Psychology, 89, 395-406.

Schneider, L., \& Schimmack, U. (2010). Examining sources of self-informant agreement in life satisfaction judgments. Journal of Research in Personality, 44, 207-212. http://doi.org/10.1016/j.jrp.2010.01.004

Sarason, S. B. (1974). The psychological sense of community: Perspectives for community psychology. San Francisco, CA: Jossey-Bass.

Suldo, S. M., \& Huebner, E. S. (2004). Does life satisfaction moderate the effects of stressful life events on psychopathological behavior during adolescence? School Psychology Quarterly, 19, 93-105. http://doi.org/10.1521/scpq.19.2.93.33313

Voracek, M. (2009). National intelligence, suicide rate, and subjective well-being. Perceptual and Motor Skills, 109(3), 718-720. https://doi.org/10.2466/pms.109.3.718-720 